\title{
Overexpression of wild-type human APP in mice causes cognitive deficits and pathological features unrelated to $A \beta$ levels
}

\author{
Ana-María Simón ${ }^{1}$, Lucio Schiapparelli ${ }^{1}$, Pablo Salazar-Colocho, Mar Cuadrado-Tejedor, Luis Escribano, \\ Rakel López de Maturana, Joaquín Del Río, Alberto Pérez-Mediavilla, Diana Frechilla*
}

Division of Neurosciences, CIMA, University of Navarra, Av. Pio XII 55, 31008 Pamplona, Spain

CIBERNED, Spain

\section{A R T I C L E I N F O}

\section{Article history:}

Received 1 September 2008

Revised 30 October 2008

Accepted 7 November 2008

Available online 28 November 2008

\section{Keywords:}

Alzheimer's disease

APP

Amyloid

Tau

Synapse

Hippocampus

Memory

\begin{abstract}
A B S T R A C T
Transgenic mice expressing mutant human amyloid precursor protein (APP) develop an age-dependent amyloid pathology and memory deficits, but no overt neuronal loss. Here, in mice overexpressing wild-type human APP $\left(\mathrm{hAPP}_{\mathrm{wt}}\right)$ we found an early memory impairment, particularly in the water maze and to a lesser extent in the object recognition task, but $\beta$-amyloid peptide $\left(A \beta_{42}\right)$ was barely detectable in the hippocampus. In these mice, hAPP processing was basically non-amyloidogenic, with high levels of APP carboxy-terminal fragments, C83 and APP intracellular domain. A tau pathology with an early increase in the levels of phosphorylated tau in the hippocampus, a likely consequence of enhanced ERK1/2 activation, was also observed. Furthermore, these mice presented a loss of synapse-associated proteins: PSD95, AMPA and NMDA receptor subunits and phosphorylated CaMKII. Importantly, signs of neurodegeneration were found in the hippocampal CA1 subfield and in the entorhinal cortex that were associated to a marked loss of MAP2 immunoreactivity. Conversely, in mice expressing mutant hAPP, high levels of $A \beta_{42}$ were found in the hippocampus, but no signs of neurodegeneration were apparent. The results support the notion of $A \beta-$ independent pathogenic pathways in Alzheimer's disease.
\end{abstract}

(c) 2008 Elsevier Inc. All rights reserved.

\section{Introduction}

Alzheimer's disease $(A D)$ is a progressive neurodegenerative disorder usually characterized by two histopathological hallmarks, amyloid plaques, mainly composed of the $\beta$-amyloid $(A \beta)$ peptide, and intracellular neurofibrillary tangles, comprising aggregates of hyperphosphorylated protein tau. Other neuropathological hallmarks, early synaptic dysfunction and selective neuronal loss, are nowadays considered the best correlate of cognitive decline in $\mathrm{AD}$ (Selkoe, 2002; Walsh and Selkoe, 2004). According to the $\beta$-amyloid hypothesis, $A \beta$ is the initiating cause of $A D$. This peptide is proteolytically generated from the larger amyloid precursor protein (APP) that is cleaved by $\beta$-secretase releasing a soluble fragment (SAPPB) and a carboxy-terminal fragment (CTF), C99, within the membrane. The $\gamma$-secretase complex cleaves the latter fragment releasing the $A \beta$ peptide and the APP intracellular domain (AICD). APP can be also processed by a non-amyloidogenic pathway that includes the proteolysis of APP by $\alpha$-secretase, within the A $\beta$ region, to generate a secreted soluble protein (SAPP $\alpha$ ) and a CTF named C83. Further cleavage of $\mathrm{C} 83$ by $\gamma$-secretase generates $\mathrm{p} 3$ peptide and the AICD fragment. Different reports indicate that not only $A \beta$ is

\footnotetext{
* Corresponding author. Fax: +34 948194715.

E-mail address: dfrech@unav.es (D. Frechilla).

1 These authors contributed equally to this work.

Available online on ScienceDirect (www.sciencedirect.com).
}

neurotoxic, but also the CTFs may alter neuronal survival. In particular, the AICD, generated from C83 or C99 fragments, has been identified in transgenic mouse brains overexpressing human APP (hAPP) as well as in AD brain tissue and may have a critical pathophysiological role (Passer et al., 2000; Shin et al., 2007).

Some studies have provided evidence for an intrinsic central role of APP in the pathogenesis of AD and have suggested that this disease may be a consequence of a disruption of APP normal function (Neve et al., 2000). APP is not only important for CNS maturation but plays also a role in cell contact and adhesion, in neuronal morphogenesis, in the maintenance of synaptic transmission and plasticity and may even induce a neurotrophic effect (Alpár et al., 2006; Priller et al., 2006; Oh et al., 2008). Accordingly, APP knockout mice develop behavioral and cognitive impairment (Dawson et al., 1999; Phinney et al., 1999). Despite the physiological role of APP, several studies have shown that APP overexpression may lead to an increased generation of toxic derivatives, $A \beta$ peptide and/or CTFs. Moreover, APP overproduction, either as a result of genomic locus duplication or altered regulatory sequences in the APP promoter region, leads to early-onset AD in humans (Cabrejo et al., 2006; Rovelet-Lecrux et al., 2006).

Several transgenic mouse models for AD carrying mutations of hAPP, presenilins, tau or different combinations have been generated for the production of an Alzheimer-type neuropathology (Van Dam and De Deyn, 2006). However, a complete mouse model recapitulating all aspects of the disease has not yet been produced. In transgenic 
mice expressing mutant hAPP it is unclear whether the cognitive deficits and histological alterations are due to mutant hAPP overexpression or to excessive production of A $\beta$ peptide or other APPderived products. Unexpectedly, we observed early memory deficits in mice overexpressing wild-type human APP despite almost undetectable $A \beta_{42}$ levels in the hippocampus and we explored possible pathogenic mechanisms involved in such a cognitive impairment. We here show that overexpression of wild-type APP may promote $A \beta$ independent pathogenic pathways resulting in signs of neurodegeneration in the hippocampus and entorhinal cortex.

\section{Materials and methods}

\section{Transgenic mice}

Transgenic hAPP ${ }_{\mathrm{wt}}$ mice overexpressing human wild-type amyloid precursor protein (line I5) were used in this study and also, in some experiments, hAPP $_{\text {swe-ind }}$ mice overexpressing hAPP with the Swedish (K670N/M671L) and Indiana (V717F) familial AD mutations (line J20; numbers refer to amino acids in APP770). In both lines, neuronal expression of hAPP was directed by the PDGF $\beta$-chain promoter. hAPP expression was approximately the same in both transgenic lines (Mucke et al., 2000). The mice were on an inbred C57BL/6J genetic background. Animals were housed four-five per cage with free access to food and water and maintained in a temperature-controlled environment on a $12 \mathrm{~h}$ light/dark cycle. All procedures were carried out in accordance with European and Spanish regulations (86/609/ CEE; RD1201/2005). This study was approved by the Ethical Committee of the University of Navarra (no. 018/05).

\section{Behavioral procedures}

Groups of 5-month-old hAPP ${ }_{\text {wt }}$ and non transgenic littermates, underwent spatial reference learning and memory in the Morris water maze (MWM) test, a hippocampus-dependent learning task. The maze was a circular tank (diameter $1.45 \mathrm{~m}$ ) filled with water at $20^{\circ} \mathrm{C}$. Mice underwent visible-platform training for three consecutive days ( 8 trials/day), and were allowed to swim to a raised platform (diameter $10 \mathrm{~cm}$ ) located above the water in the same position over trials. Hidden-platform training was conducted over 9 consecutive days (4 trials/day). Mice had $60 \mathrm{~s}$ to find a hidden platform submerged $1 \mathrm{~cm}$ beneath the surface of the water and invisible to the mice while swimming. Several large visual cues were placed in the room to guide the mice to the hidden platform. Mice failing to reach the platform were guided onto it. All the animals were allowed to rest on the platform for $20 \mathrm{~s}$ and then removed from the platform and returned to their home cage. At the beginning of 4 th, 7 th, and 9 th day of the task, a probe trial in which the platform was removed from the pool was conducted, and the mice were permitted to search the platform for $60 \mathrm{~s}$. All trials were monitored by a camera using an HVS water maze program for analyses of escape latencies and percent time spent in each quadrant of the pool during probe trials (analysis program Ethovision, Wageningen, The Netherlands). Mice that were unable to reach the visible-platform or mice exhibiting abnormal swimming patterns or persistent floating were excluded from data analyses.

The apparatus for the object recognition test consisted of a dark open box $(50 \times 35 \times 50 \mathrm{~cm}$ high), illuminated by a $60 \mathrm{~W}$ lamp suspended $120 \mathrm{~cm}$ above the box. The different objects consisted in red rectangular prisms $(2 \times 2 \times 8 \mathrm{~cm}$ high $)$ and white pyramids $(5 \times 5 \times 5 \mathrm{~cm}$ high $)$ among others. These objects could not be displaced by the mice. In the week preceding testing, the animals were handled daily and adapted to the room in which the behavioral procedures were performed. The object recognition test was performed as described elsewhere (Ennaceur and Delacour, 1988; Schiapparelli et al., 2006) with minor modifications. One h before testing, the mice were allowed to explore the apparatus without objects for $5 \mathrm{~min}$. After habituation, two familiarization sessions were given (T1 and T2, 10 min apart), in which the animals were left to explore for 10 min two identical objects that were placed in opposite sides of the apparatus $10 \mathrm{~cm}$ from the side wall. The choice trial (T3), in which memory retention was tested, was given $24 \mathrm{~h}$ after T2. In this session, two objects were presented, one of the objects used in familiarization session (T1 and T2) and other different in shape and colour; therefore the mice were re-exposed to a familiar (F) and a novel object $(\mathrm{N})$. Exploration was defined as directing the nose to an object at a distance $\leq 2 \mathrm{~cm}$ and/or touching the object with the nose. To avoid the presence of olfactory trails, the apparatus and the objects were thoroughly cleaned after each trial. The time spent by the animals in exploring each object was recorded manually by using a stopwatch. The reaction to a novel object during T3 was measured by calculating the discrimination ratio (D): time spent exploring the novel object over total exploration time. Consequently, a ratio of 0.5 reflects equal exploration of the familiar and the novel object, indicating no learning retention.

\section{Determination of $A \beta$ levels}

Hippocampal $A \beta_{42}$ was measured by using a sensitive sandwich ELISA kit from Biosource (Camarillo, CA, USA). In brief, hippocampus was weighed and homogenized in $300 \mu \mathrm{l}$ of ice-cold guanidine buffer (5 M guanidine $\mathrm{HCl} / 50 \mathrm{mM}$ Tris $\mathrm{HCl} \mathrm{pH}$ 8.0). The homogenates were mixed for $4 \mathrm{~h}$ at room temperature and $10 \mu \mathrm{l}$ were diluted 1:20 in Dulbecco's phosphate buffered saline containing 5\% BSA and $0.03 \%$ Tween-20 (DPBS-BSAT) supplemented with protease inhibitor cocktail (Complete ${ }^{\mathrm{TM}}$ Protease Inhibitor Cocktail, Roche Diagnostics, Mannheim, Germany) followed by centrifugation at $16,000 \mathrm{~g}$ for $20 \mathrm{~min}$ at $4{ }^{\circ} \mathrm{C}$. Fifty microliters of this supernatant were loaded directly onto ELISA plates in duplicate and manufacturer instructions were followed. The $A \beta$ standards were prepared in a buffer with the same composition of final hippocampal samples (0.25 M guanidine $\mathrm{HCl} / 2.5 \mathrm{mM}$ Tris $\mathrm{HCl}$ pH 8.0 in DPBS-BSAT).

\section{Production of protein extracts}

For APP carboxy-terminal fragments determination, the hippocampus was homogenized in a buffer containing SDS $2 \%$, Tris- $\mathrm{HCl}$ (10 mM, pH 7.4), protease inhibitors (Complete ${ }^{\mathrm{TM}}$ Protease Inhibitor Cocktail, Roche) and phosphatase inhibitors $\left(0.1 \mathrm{mM} \mathrm{Na}_{3} \mathrm{VO}_{4}, 1 \mathrm{mM}\right.$ $\mathrm{NaF}$ ). The homogenates were sonicated for $2 \mathrm{~min}$ and centrifuged at $100,000 \mathrm{~g}$ for $1 \mathrm{~h}$. Aliquots of the supernatant were frozen at $-80^{\circ} \mathrm{C}$ and protein concentration was determined by the Bradford method using the Bio-Rad protein assay (Bio-Rad, Hercules, CA, USA). For some experiments, equal amounts of protein $(350 \mu \mathrm{g})$ were treated with hexafluoroisopropanol (HFIP, Sigma, Germany) to a final concentration of $30 \%$ and the samples incubated for $1 \mathrm{~h}$ at $30{ }^{\circ} \mathrm{C}$. These HFIP treated extracts were then used for Western blot analysis.

To obtain the membrane-enriched protein fraction (P2 membrane proteins), a previously described method (Dunah et al., 2000) was used. The hippocampus was homogenized in ice-cold Tris-EDTA buffer (10 mM Tris- $\mathrm{HCl}$ and 5 mM EDTA, pH 7.4), containing $320 \mathrm{mM}$ sucrose and the protease and phosphatase inhibitors previously described. The tissue homogenate was centrifuged at $700 \mathrm{~g}$ for $10 \mathrm{~min}$. The supernatant was centrifuged again at $37,000 \mathrm{~g}$ for $40 \mathrm{~min}$ at $4{ }^{\circ} \mathrm{C}$. The pellet (P2) was resuspended in $10 \mathrm{mM}$ Tris- $\mathrm{HCl}$ buffer ( $\mathrm{pH} 7.4$ ), containing the enzyme inhibitor mixture described above. In both cases, protein concentration was determined (Bio-Rad protein assay) and aliquots were stored at $-80{ }^{\circ} \mathrm{C}$ until used. For Western blot analysis, aliquots of the P2 membrane fraction were solubilized by adding 0.1 volume of $10 \%$ sodium deoxycholate in $500 \mathrm{mM}$ Tris- $\mathrm{HCl}$ buffer ( $\mathrm{pH}$ 9). The samples were incubated for $30 \mathrm{~min}$ at $36{ }^{\circ} \mathrm{C}$ and diluted by adding $0.1 \mathrm{vol}$ of $500 \mathrm{mM}$ Tris- $\mathrm{HCl}(\mathrm{pH} \mathrm{9}) / 1 \%$ Triton X-100. After a centrifugation at $37,000 \mathrm{~g}$ for $10 \mathrm{~min}$ at $4{ }^{\circ} \mathrm{C}$, the supernatant was frozen at $-80^{\circ} \mathrm{C}$. 


\section{Western blotting}

For Western blot analysis of APP-derived fragments, aliquots of the protein extracts were mixed with XT sample buffer ${ }^{\mathrm{TM}}$ plus XT reducing agent $^{\mathrm{TM}}$ or Tricine sample buffer ${ }^{\mathrm{TM}}$ (Bio-Rad) and boiled for $5 \mathrm{~min}$. Proteins were separated in a Criterion ${ }^{\mathrm{TM}}$ precast Bis-Tris $4-12 \%$ gradient precast gel or Tris/Tricine precast gel 16.5\% (Bio-Rad) and transferred to a PVDF membrane with $0.2 \mu \mathrm{m}$ removal rating (Hybond LFP, Amersham Biosciences, UK). The membranes were blocked with $5 \%$ milk, $0.05 \%$ Tween-20 in TBS followed by overnight incubation with the following primary antibodies: mouse monoclonal 6E10 (amino acids $1-17$ of $A \beta$ peptide, $1: 1000$, Chemicon), rabbit polyclonal anti-APP C-terminal (amino acids 676-695) (1:2000, Sigma-Aldrich, St. Louis, MO, USA), rabbit anti-phosphoAPP(Thr668) (1:500, Cell Signaling Technology, Beverly, MA, USA) and mouse monoclonal anti $\alpha$-tubulin (1:10,000, Sigma).

For determination of other proteins, samples were mixed with an equal volume of $2 \times$ Laemmli sample buffer, resolved onto SDSpolyacrylamide gels and transferred to nitrocellulose membrane (Hybond ECL, Amersham Biosciences). The membranes were blocked with $5 \%$ milk, $0.05 \%$ Tween-20 in PBS or TBS followed by overnight incubation with the following primary antibodies: monoclonal antitau (clone Tau46, 1:3000, Sigma), mouse monoclonal PHF-1 (1:100, a gift from Dr. J. Avila, CBM, Madrid), rabbit polyclonal anti-ERK1/2 (1:1000, Upstate), mouse monoclonal anti-phospho ERK1/2 (1:1000, Upstate), rabbit polyclonal anti-GSK3 $\beta$ (Ser9) (1:1000, Cell Signaling), rabbit polyclonal anti-GluR1 $(0.2 \mu \mathrm{g} / \mathrm{ml}$, Chemicon, Temecula, CA, USA), rabbit polyclonal anti-GluR2 $/ 3(0.1 \mu \mathrm{g} / \mathrm{ml}$, Chemicon $)$, rabbit polyclonal anti-NR1 (1:1000, Upstate), rabbit polyclonal anti-NR2A (1:1000, Upstate), rabbit polyclonal anti-NR2B (1:1000, Upstate), mouse monoclonal anti-CaMKII (1:10,000, Chemicon), mouse monoclonal anti-phospho CaMKII(Thr286) (1:1000, Upstate), mouse monoclonal anti-PSD95 (1:300, Chemicon) and mouse monoclonal anti $\alpha$-tubulin $(1: 10,000$, Sigma) in the corresponding buffer.

In all cases, membranes were washed three times in PBS or PBS/ Tween20 at room temperature, and HRP-conjugated anti-rabbit or anti-mouse antibody (Dako Denmark; dilution 1:2000) was added and incubated for $1.5 \mathrm{~h}$. Immunolabelled protein bands were detected using an enhanced chemiluminiscence system (ECL Plus detection system, Amersham Biosciences) followed by autoradiographic exposure to Hyperfilm ${ }^{\mathrm{TM}} \mathrm{ECL}$ (Amersham Biosciences). The quantification of signals was performed using Scion Image software (Scion Corporation) or a Storm ${ }^{\circledR} 860$ imaging systems (Amersham Biosciences).

\section{Tissue processing for histochemistry}

Under xylazine/ketamine anesthesia, animals were perfused transcardially with saline and $4 \%$ paraformaldehyde in phosphate buffer (PB). After perfusion, brains were removed, post-fixed in the same fixative solution for $1 \mathrm{~h}$ at room temperature and cryoprotected in $30 \%$ sucrose solution in PB overnight at $4{ }^{\circ} \mathrm{C}$. Microtome sections (30- $\mu \mathrm{m}$-thick) were cut coronally through the entire hippocampus, collected free-floating and stored in 30\% ethylene glycol, 30\% glycerol, and $0.1 \mathrm{M}$ PB at $-20{ }^{\circ} \mathrm{C}$ until processed.

\section{Nissl staining quantification}

Some sections were processed for histological assessment of damage by staining with thionin (Nissl staining). Quantitative assessment of cell density in the pyramidal layer of CA1 hippocampal subfield and in the entorhinal cortex was performed in stained coronal sections with a light microscope using a $4 \times$ objective and the analySIS image system (Olympus). Video images of each region of interest were captured on $30 \mu \mathrm{m}$ sections, and a threshold of optical density was obtained that discriminated staining from background. Densitometric quantification of the percent area of CA1 covered by the pyramidal layer or the density of cells stained along lateral sections of the entorhinal cortex was performed using six sections per mouse $(n=5)$. Brain sections from mice to be compared in any given experiment were blind coded and processed in parallel.

\section{Immunohistochemistry}

Five free floating tissue sections comprising the hippocampal formation of five animals per group were processed for immunohistochemistry. Brain sections were washed $(3 \times 10 \mathrm{~min})$ with PBS $0.1 \mathrm{M}$ ( $\mathrm{pH} 7.4$ ) and incubated in blocking solution (PBS containing $0.5 \%$ Triton X-100, $0.1 \%$ BSA and $2 \%$ normal goat serum) for $2 \mathrm{~h}$ at room temperature. For 6 E10 immunostaining, sections were incubated in $70 \%$ formic acid for $7 \mathrm{~min}$ to expose the epitope. Primary and secondary antibodies were diluted in the blocking solution. Sections were incubated with the primary antibodies for $24 \mathrm{~h}$ at $4{ }^{\circ} \mathrm{C}$, washed with PBS and incubated with the secondary antibodies for $2 \mathrm{~h}$ at room temperature, protected from light. The primary antibodies used were: mouse monoclonal 6E10 (amino acids 1-17 of $A \beta$ peptide, 1:200, Chemicon), rabbit polyclonal anti-APP-CT20 (amino acids 751-770, 1:1000, Calbiochem), monoclonal mouse anti-NeuN (1:300, Chemicon) and rabbit polyclonal anti-MAP2 (1:1000, Chemicon). Secondary antibodies used were Alexa Fluor 488 goat anti-mouse, highly crossadsorbed, Alexa Fluor 488 goat anti-rabbit, highly cross-adsorbed, and Alexa Fluor 546 goat anti-rabbit, highly cross-adsorbed (all 1:200, Molecular Probes,Eugene, Oregon, USA). Sections were mounted on super frost plus slides, air dried for $24 \mathrm{~h}$, rinsed in toluene $(2 \times 5 \mathrm{~min})$, and cover-slipped with DPX mounting medium. To ensure comparable immunostaining, sections were processed together under identical conditions. For the assessment of non-specific primary immunostaining, some sections from each experimental group were incubated without the primary antibodies; in this case no immunostaining was observed. Non-specific secondary immunostaining was also evaluated by incubating sections with primary and its non-respective secondary antibodies; again, no immunostaining was observed. Fluorescence signals were detected with confocal microscope LSM 510 Meta (Carl Zeiss, Germany); objective Plan-neofluar $40 \times / 1.3$ oil DIC. Sections were evaluated in Z-series ( $0.4 \mu \mathrm{m}$ steps) using LSM 510 Meta software.

\section{Results}

\section{Memory deficits in mice expressing human APP}

In the Morris water maze, all experiments with transgenic mice $\left(\mathrm{hAPP}_{\mathrm{wt}}\right)$ and non transgenic littermates were performed on a blind basis. Only one animal, a non transgenic littermate, was excluded from the analysis as it was unable to reach the visible-platform. No significant differences among groups were found during the days of visible platform training (Fig. 1A). In the spatial component of the test (invisible platform), there were significant differences among groups $(P<0.01)$. hAPP ${ }_{\text {wt }}$ mice showed significant deficits $(P<0.05$ or better $)$ every training day when compared to non transgenic mice (Fig. 1B). In the probe trial which provides a putative measure of memory retention, an impairment was found. As it has been suggested that the sensitivity of the MWM test can be increased by giving shorter probe trials (Gerlai, 2001), we analyzed the performance of mice during the first $15 \mathrm{~s}$ of every probe trial (Fig. 1C). ANOVA showed a significant difference between groups, and $\mathrm{hAPP}_{\mathrm{wt}}$ mice did not retain a clear bias for the platform location $24 \mathrm{~h}$ after the last training session on days 4,7 and 9 .

Object recognition memory was analyzed at two different ages in transgenic mice. At early stages, 5 months of age, hAPP ${ }_{w t}$ mice did not show impaired recognition memory with a discrimination index ( $\mathrm{DI}=0.71 \pm 0.020)$ similar to the non-transgenic animals $(\mathrm{DI}=0.72 \pm 0.38)$. 
A

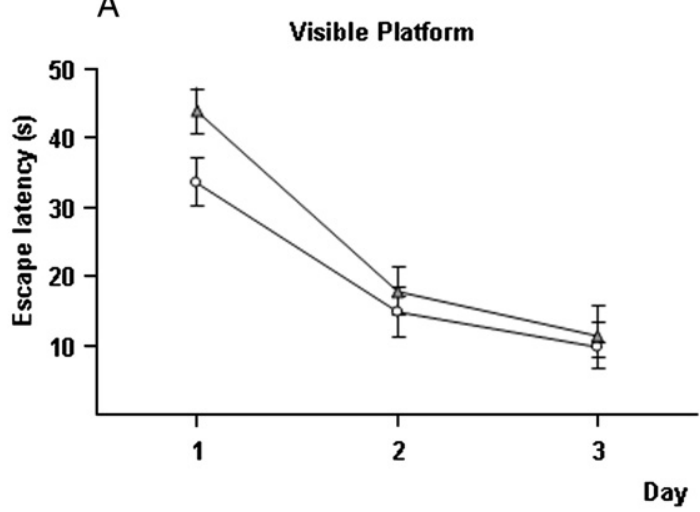

C

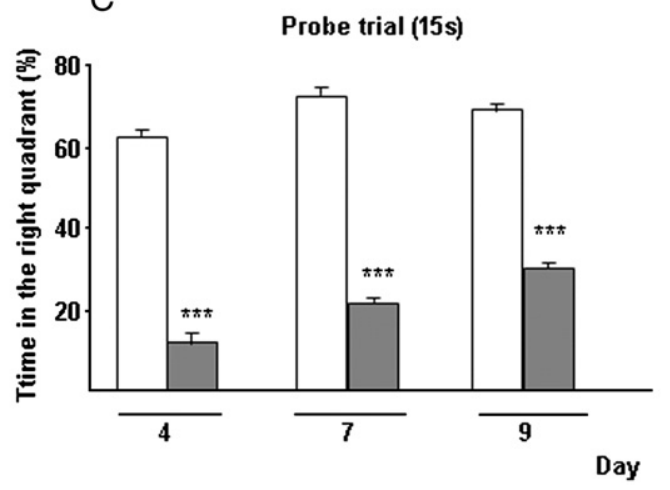

B
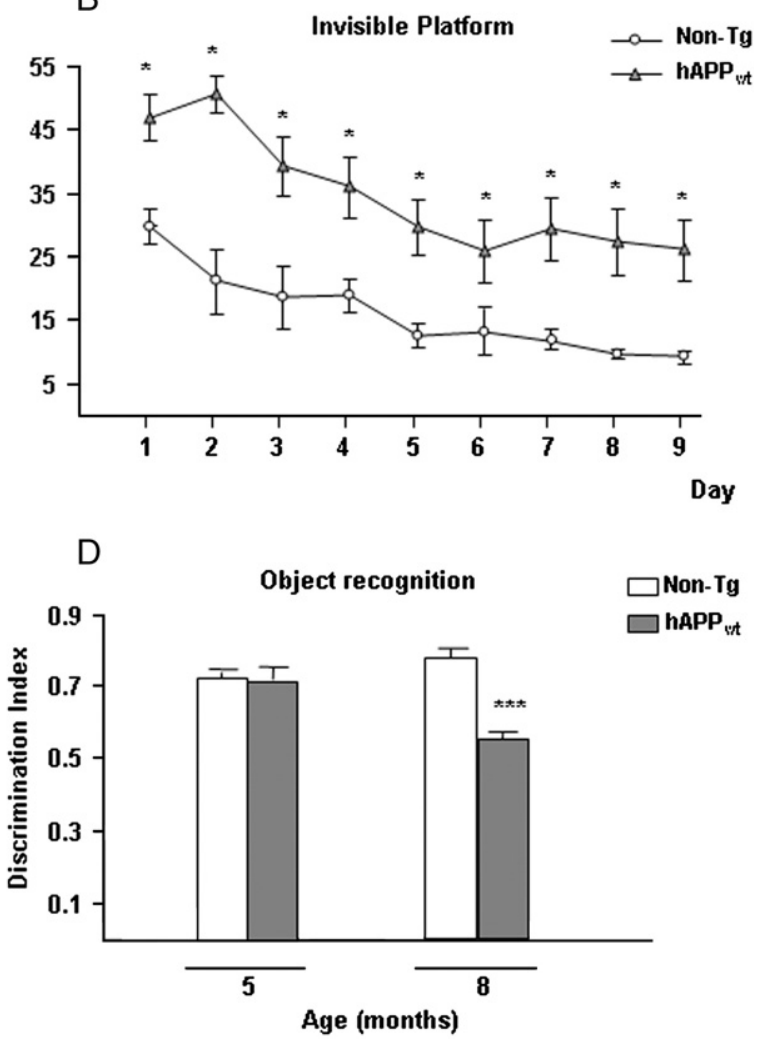

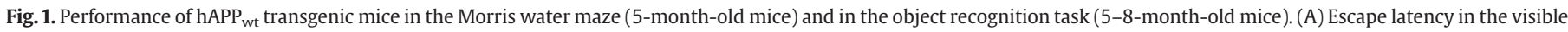

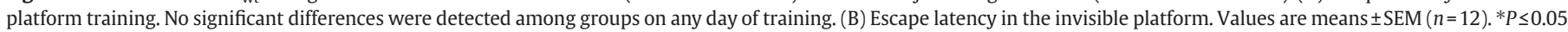

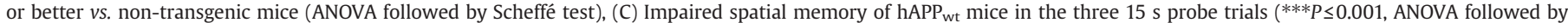

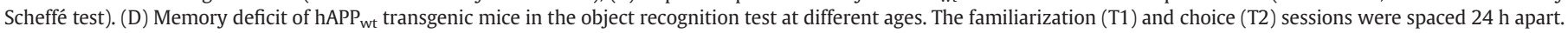
Values are means \pm SEM ( $n=19-32$ in control groups and $n=11-19$ in transgenic groups). ${ }^{* * *} P<0.001$ vs. non-transgenic mice (ANOVA followed by Scheffé test).

Nevertheless, at 8 months of age, recognition memory impairment was apparent in $\mathrm{hAPP}_{\mathrm{wt}}$ mice with a discrimination index significantly lower than non transgenic controls $(P<0.001)$ (Fig. 1D). The discrimination indexes were $0.55 \pm 0.023$ for $\mathrm{APP}_{\mathrm{wt}}$ mice, and $0.77 \pm 0.032$ for nontransgenic controls.

\section{A $\beta$ levels in APP transgenic mice}

Hippocampal levels of $A \beta_{42}$ were determined in 5- and 8-monthold hAPP ${ }_{w t}$ and $\mathrm{hAPP}_{\text {swe-ind }}$ mice. As shown in Fig. $2 \mathrm{~A}$, in the hippocampus from animals overexpressing wild-type hAPP barely detectable levels of $A \beta_{42}$ were found whereas mice overexpressing mutant hAPP showed elevated levels of this peptide. So it seems that in the transgenic lines used in this study, the presence of $A \beta_{42}$ is dependent of the presence in APP of mutations related to familial AD.

Using 6E10 antibody, that recognizes the amino-terminal region of $A \beta$, we performed Western-blot analysis in hippocampal protein extracts from $\mathrm{hAPP}_{\mathrm{wt}}$ and $\mathrm{hAPP}_{\text {swe-ind }}$ transgenic mice. As shown in Fig. 2B, we detected in blots from both transgenic lines a band at $105 \mathrm{kDa}$ (corresponding to human APP) and an additional band at $\sim 56 \mathrm{kDa}$. It is important to note that the intensity of the latter band was lower in $\mathrm{hAPP}_{\mathrm{wt}}$ mice than in mice overexpressing mutant hAPP. This band seems to correspond in size with the recently characterized $A \beta$ dodecamer, termed $A \beta * 56$, which correlates with cognitive deficits in transgenic mice. To confirm that this band was indeed an $A \beta$ oligomer, we treated the hippocampal homogenates with HFIP $30 \%$, a compound known to disrupt $A \beta$ oligomers, for $1 \mathrm{~h}$. As shown in Fig. $2 \mathrm{~B}$, after treatment with this solvent the band disappeared indicating the depolymerization of the oligomer complex.

\section{Analysis of APP-derived carboxy-terminal fragments}

We analyzed the expression of APP-derived CTFs by immunohistochemical and Western blot techniques. In animals overexpressing the human wild-type APP, using 6 E10 antibody we found a moderate labelling in neuronal cell bodies of the pyramidal cell layer of CA1 (Fig. 3A) and an intense and diffuse immunoreactivity in the cerebral cortex and adjacent areas as well as in the hilus of dentate gyrus (not shown). Because the antibody used in this study recognizes amino acids 1-17 of $A \beta$ peptide, it is difficult to precise whether the labelling corresponded to this peptide or to APP. Nevertheless, taking into account that these mice showed virtually undetectable levels of $A B$ in the hippocampus (Fig. $2 A$ ), it is possible to suppose that the immunoreactivity against $6 \mathrm{E} 10$ corresponded to APP, probably located in neuritic processes. No 6E10 immunoreactive senile plaques were detected in brain sections from aged $\mathrm{hAPP}_{\mathrm{wt}}$ mice (15-20 months, not shown). When the CT-20 antibody was used, we found a selective location in neuronal cell bodies in $\mathrm{hAPP}_{\mathrm{wt}}$ mice (Fig. 3B). This labelling probably corresponds to the presence of carboxy-terminal fragments derived from the processing of APP and remaining inside the neuron.

We analyzed by Western blot the levels of the CTFs C83, C99 and AICD in transgenic mice overexpressing $\mathrm{hAPP}_{\mathrm{wt}}$ and we found that these mice produced much more C83 than C99 $(P<0.001)$ with a ratio of $3.01 \pm 029$ (Fig. 3C). This could be related to the facilitated $\alpha$ secretase metabolism of APP. In order to obtain better resolution of small peptides derived from APP, we performed analysis by Western blot in hippocampal extracts using Tris/tricine PAGE 16.5\% gels. Employing an antibody that recognizes the C-terminal fragment of 
A
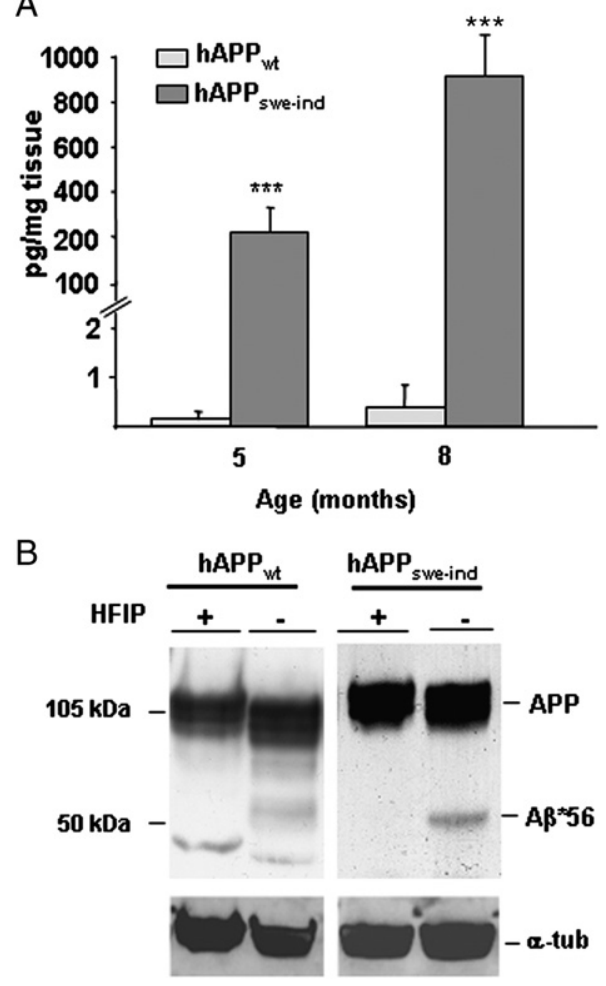

Fig. 2. $A \beta$ peptides in the hippocampus of $h A P P_{w t}$ and $h A P P_{\text {swe-ind }}$ transgenic mice. (A) Levels of $A \beta 42$ determined by ELISA. Values are means $\pm \operatorname{SEM}(n=5), * * * P<0.001$ vs. hAPP $_{\text {wt }}$ mice (Student's $t$ test). (B) Western blot analysis of hippocampal extracts using $6 \mathrm{E} 10$ antibody revealed in both transgenic cohorts a $56 \mathrm{kDa}$ band that disappeared after treatment with HFIP.

APP we detected in hippocampal protein preparations from hAPP $\mathrm{wt}_{\mathrm{t}}$ mice a strong band, immediately below C83 carboxy-terminal fragment at about $6 \mathrm{kDa}$ molecular weight, probably corresponding to AICD fragment (Fig. 3C).
Phosphorylation of C83 and C99 fragments at Thr668

Given the importance of the phosphorylation status of APP-derived CTFs, both in processing and function, we also analyzed the levels of phosphorylated C83 and C99 at the recognized Thr668 residue. The $\mathrm{hAPP}_{\mathrm{wt}}$ mice showed similar levels of pC99 and pC83 (Fig. 4) in spite of the significantly higher expression of C83. By analyzing the pC83/C83 and pC99/C99 ratios, we found that the latter was significantly higher $(P<0.001)$ in $\mathrm{hAPP}_{\mathrm{wt}}$ mice (Fig. 4).

Increased levels of phosphorylated tau in $h A P P_{w t}$ transgenic mice

We next explored another possible neuropathological correlate of memory impairment in transgenic $\mathrm{hAPP}_{\mathrm{wt}}$ mice. We measured tau phosphorylation at the epitopes recognized by the PHF-1 antibody (phosphorylated Ser 396 and 404 according to the residue numbering of the longest human tau isoform of $441 \mathrm{aa}$ ), an antibody commonly employed in neuropathological studies, that recognizes aberrantly hyperphosphorylated epitopes on tau. Five month-old hAPP $\mathrm{wt}_{\mathrm{wt}}$ and $\mathrm{hAPP}_{\text {swe-ind }}$ transgenic mice, in particular the latter line, displayed significantly elevated levels of phosphorylated tau as compared to non-transgenic animals. No change in non-phosphorylated tau levels was found (Fig. 5).

We then looked for changes in kinase activity accounting for the enhanced tau phosphorylation. No change in GSK3 $\beta$ activity was found (not shown). However the observed increase of tau phosphorylation in $\mathrm{hAPP}_{\mathrm{wt}}$ mice was accompanied by activation of ERK1/2, evaluated by measuring the levels of phosphorylated ERK1/2 which were increased by more than three-fold (not shown). Again, total levels of the non-phosphorylated enzyme were not modified.

\section{Effect of wild-type hAPP overexpression on synapse-associated proteins}

We analyzed the possible consequences of wild-type hAPP overexpression on proteins directly implicated in processes of synaptic plasticity, particularly in memory consolidation. As shown in Fig. 6, in $\mathrm{hAPP}_{\mathrm{wt}}$ mice there was an important loss of AMPA (GluR1, GluR2/3) and NMDA (NR1, NR2A, NR2B) receptor subunits in hippocampal

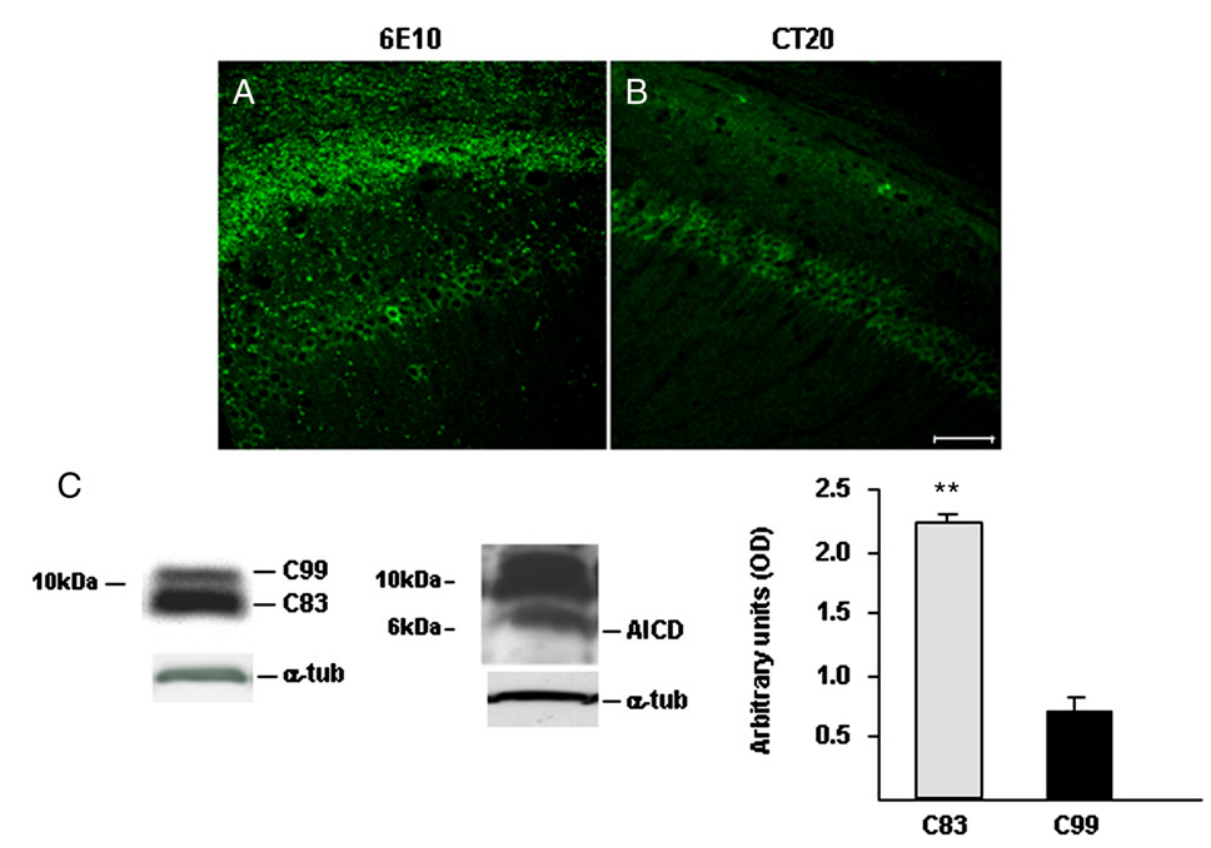

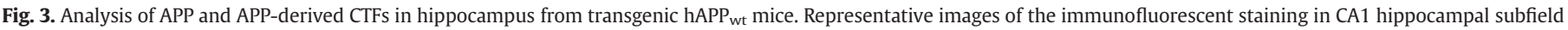

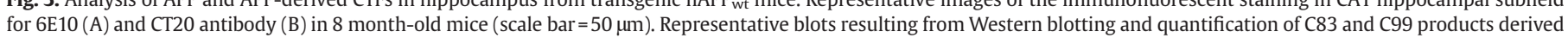
from APP processing and AICD fragment (C) in 5-month-old mice. Quantified values are means \pm SEM ( $7-8$ animals per group) of optical densities ( $* * P<0.01$, Student's $t$ test). 

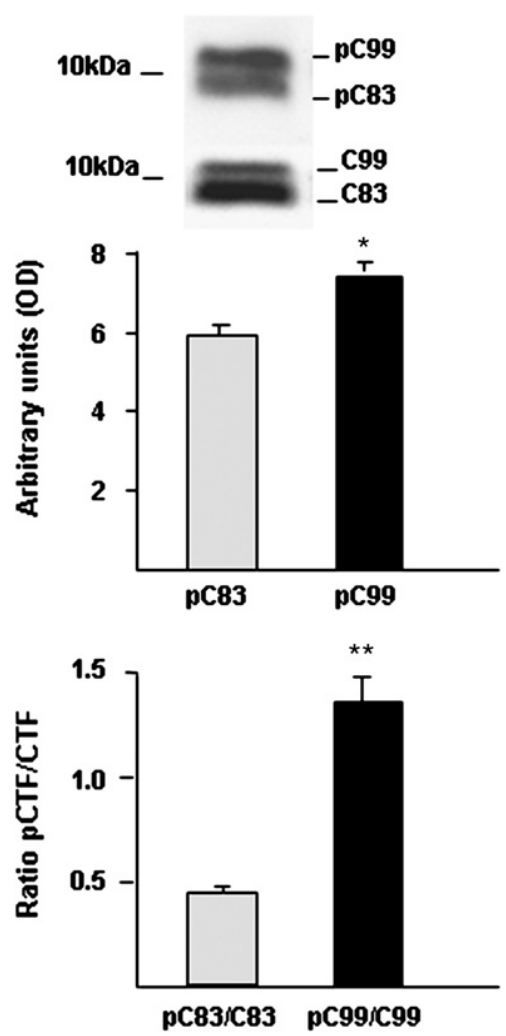

Fig. 4. Levels of CTFs (C83 and C99) phosphorylated at Thr668 in hippocampal protein extracts from 5-month-old hAPP wt mice. Experiments were performed in duplicate. Values are means \pm SEM (4-5 animals per group) of optical density. Significant differences: $* P<0.05$, ${ }^{*} * P<0.01$, Student's $t$ test.

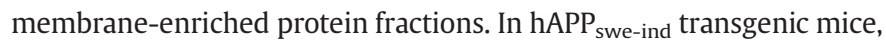
however, GluR1 subunit was significantly reduced but all other AMPA and NMDA receptor subunits were not at all affected (not shown). We also found in $\mathrm{hAPP}_{\mathrm{wt}}$ mice a significant decrease in the activity of CaMKII, evaluated by determination of levels of pCaMKII (Thr286), which was not accompanied by changes in total levels of the enzyme (Fig. 6). On the other hand, reduced levels of the postsynaptic marker PSD95 were apparent in these mice. These findings, together with the decreased immunoreactivity for the dendritic marker MAP2 (see below), indicate an important alteration in synaptic function in mice overexpressing wild-type hAPP.

\section{Signs of neurodegeneration in $h A P P_{w t}$ transgenic mice}

To assess the extent of neurodegenerative alterations in $\mathrm{hAPP}_{\mathrm{wt}}$ mice, histological analysis was performed using stains and antibodies against markers of neuronal integrity in areas sensitive to neuronal loss in $\mathrm{AD}$ such as the hippocampus and the entorhinal cortex. Compared with non-transgenic controls and also with transgenic mice expressing mutant APP, hAPP ${ }_{\mathrm{wt}}$ mice displayed decreased Nissl staining in CA1, suggesting a reduced cell density, quite clear at the early age of 5 months (data not shown), and evident at 8 months (Figs. 7A-C). This decrease seems to correspond to a loss of neurons in this area evidenced by the decreased level of immunoreactivity for the neuronal-specific marker NeuN (small box in Figs. 7A-C). This apparent cell density decrease was also present in the entorhinal cortex of hAPP ${ }_{w t}$ mice but not in transgenic mice expressing mutant APP (Figs. 7D-F). These signs of neurodegeneration were associated to a marked loss of immunoreactivity for MAP2 in 8-month-old hAPP ${ }_{\text {wt }}$ mice (Figs. 7G-I). Quantitative studies in the CA1 subfield and in the entorhinal cortex of $\mathrm{hAPP}_{\mathrm{wt}}$ mice revealed a significant percent reduction in the area of CA1 covered by the pyramidal layer and in the density of cells stained along the entorhinal cortex (Figs. 7J, K).

\section{Discussion}

In this study, we found that transgenic mice expressing wild-type human APP $\left(\mathrm{hAPP}_{\mathrm{wt}}\right)$ manifested multiple pathological features including cognitive deficits in two experimental tasks, Morris water maze and object recognition, and severe histopathological abnormalities affecting the cytoskeleton as well as signs of synaptic dysfunction. Remarkably, a significant reduction in Nissl staining in the hippocampus and entorhinal cortex, suggesting cell loss, was also found. These alterations were observed in the presence of almost undetectable levels of $A \beta$ peptide but concurred with an early increase in phosphorylated tau protein and elevated levels of APP-derived CTFs.

There was a difference in the onset of memory deficits in $\mathrm{hAPP}_{\mathrm{wt}}$ mice depending on the test considered, probably due to the cognitive demand of each task and to the degree of brain region affectation. Spatial memory performance requires a larger hippocampal integrity than does recognition memory (Broadbent et al. 2004), whereas the latter is more dependent on other brain regions, such as the perirhinal cortex (Winters and Bussey 2005). We observed that spatial memory was markedly impaired in 5 month-old animals, suggesting an early disruption of hippocampal function. In the object recognition task, visual discrimination memory of hAPPwt mice was also impaired but at a later age, 8 months. In consonance with our results, pronounced object discrimination memory impairment has been found in different APP transgenic lines with familial AD-related mutations (Dewachter et al., 2002; Zhang et al. 2006). In other transgenic APP mice, spatial memory was severely affected while recognition memory was either intact (Chen et al., 2000) or an age-dependent decrease was found (Dodart et al., 1999).

Along with the cognitive impairment, we found that hAPP ${ }_{w t}$ mice presented cytoskeletal alterations as well as synaptic pathology, key pathological features of Alzheimer's disease. Particularly, we found an age-related decrease in dendritic integrity, defined by MAP2 immunoreactivity, and reduced levels of PSD95 protein, the major component of postsynaptic density, which is affected in AD. hAPPwt mice also showed an increased phosphorylation of tau protein, an event directly related to stability of cytoskeleton and associated to AD.
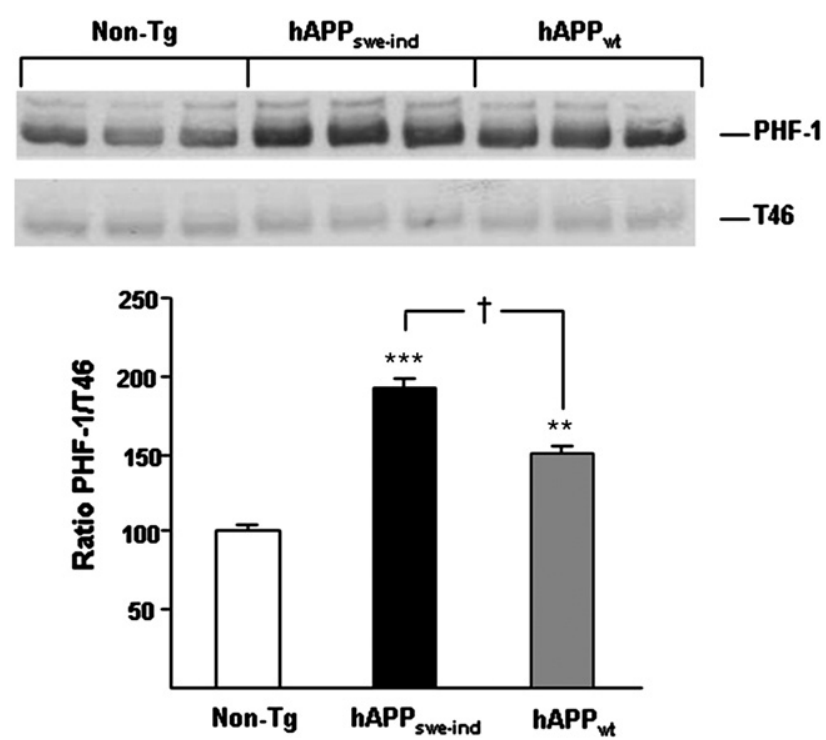

Fig. 5. Tau hyperphosphorylation in the hippocampus from 5-month-old hAPP ${ }_{w t}$ and $\mathrm{hAPP}_{\text {swe-ind }}$ transgenic mice. Values are means \pm SEM of optical density $(n=6-14)$. ${ }^{* *} P<0.01,{ }^{* * *} P<0.001$ vs. non-transgenic mice; ${ }^{\dagger} P<0.05$ vs. $\mathrm{hAPP}_{\mathrm{wt}}$ mice (ANOVA followed by Scheffé test). 

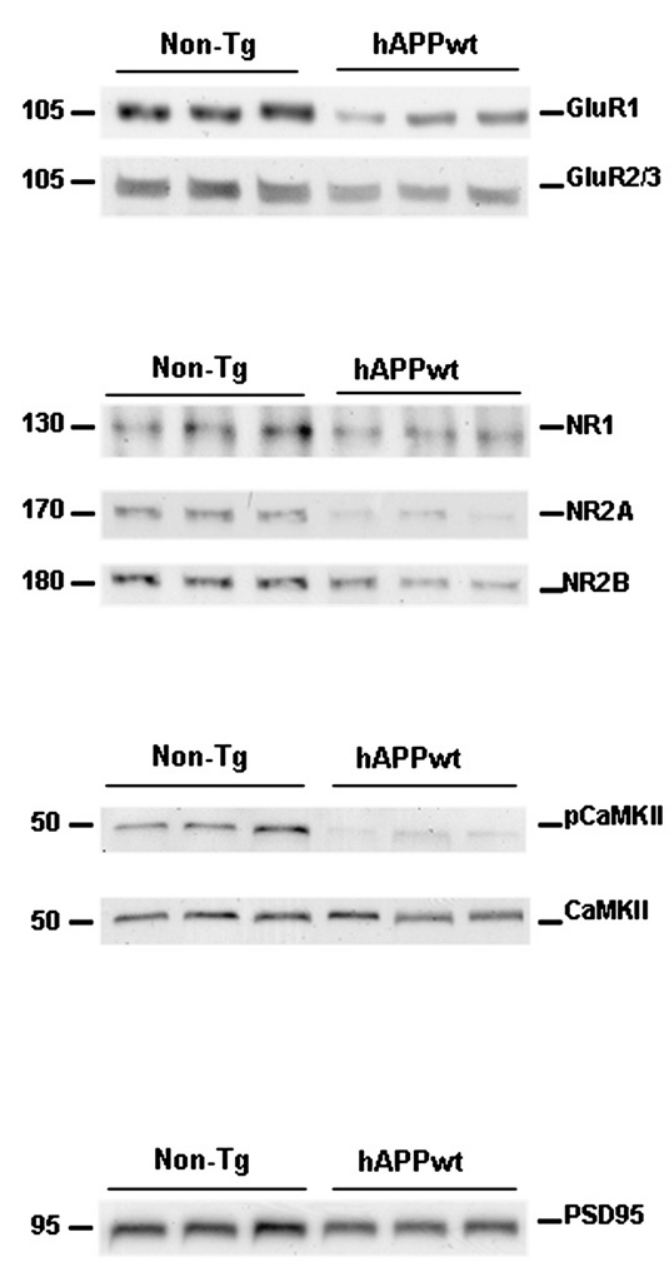
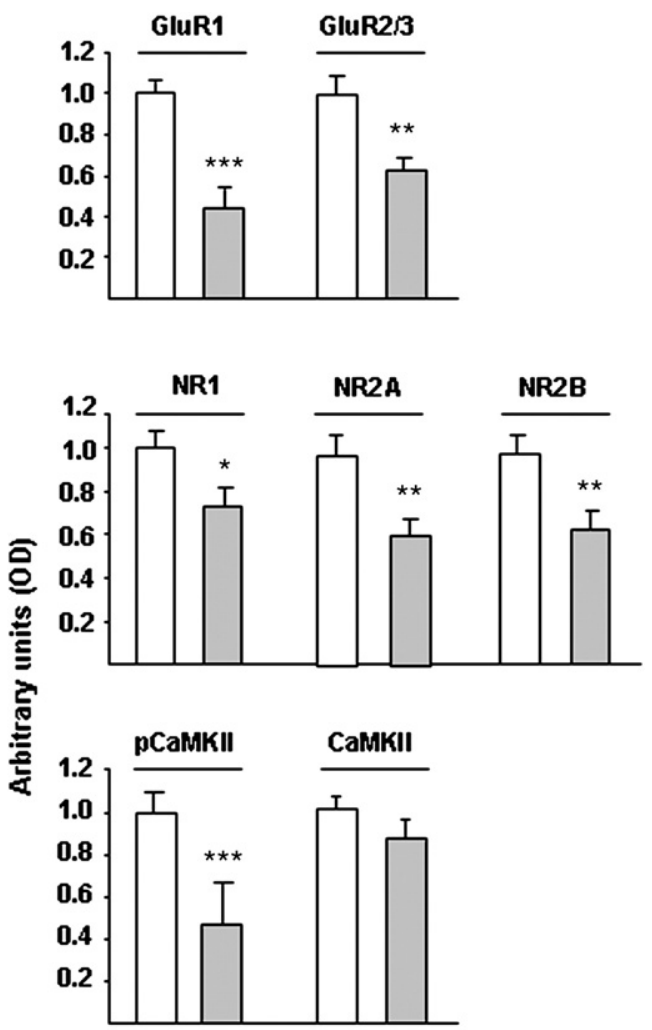

PSD95

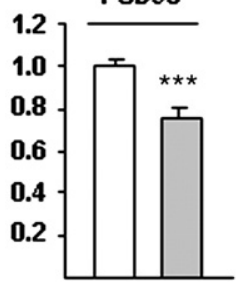

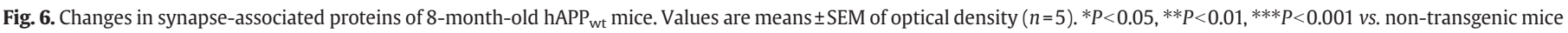
(Student's $t$ test).

By analyzing enzymes implicated in tau phosphorylation, we did not find changes in GSK3 $\beta$ activity, but high levels of activated ERK1/2, an enzyme that phosphorylates tau at epitopes recognized by PHF1 antibody, were found in the hippocampus. Abnormal tau phosphorylation occurs in a sequential manner, tau ERK1/2 sites being among the first to be phosphorylated (Echeverria et al., 2004). A similar situation has been observed in the human brain, where activation of this enzyme is associated to early tau deposition in neurons (Ferrer et al. 2001). It seems however that abnormal tau phosphorylation is not the primary cause for neurodegeneration as tau protein phosphorylation was still higher in $\mathrm{hAPP}_{\text {swe-ind }}$ mice that did not show neurodegeneration signs. Notably, we also found in $\mathrm{hAPP}_{\mathrm{wt}}$ mice a significant decrease of proteins directly implicated in processes of synaptic plasticity, particularly memory consolidation. There was a reduced membrane expression of NMDA and AMPA receptor subunits which could interfere with an appropriate excitatory transmission and, consequently, with the induction and maintenance of memory respectively (Lu et al. 2001). There was also a profound decrease in $\mathrm{Ca}^{2+}$ independent activated CaMKII in membrane preparations, without changes in total levels of the enzyme. This protein is particularly enriched in postsynaptic regions and has been considered a crucial memory molecule (Fink and Meyer, 2002). All of these findings are indicative of a synaptic dysfunction in $\mathrm{hAPP}_{\mathrm{wt}}$ mice. Furthermore, neurons from hAPP wt mice showed a very low NeuN immunolabelling suggesting a degenerative process. An apparent age-dependent reduction in cell density, estimated by quantification of Nissl stained sections, was observed in the hippocampus and in the entorhinal cortex. This latter finding is of particular relevance because most currently available animal models of AD show cognitive deficits and neuropathological alterations but fail to recapitulate the extensive neuronal loss observed in the later stages of human disease (McGowan et al., 2006).

It is remarkable that the early cognitive impairment and neuropathological alterations here found in transgenic mice overexpressing wild-type human APP were not related to abnormal hippocampal levels of $A \beta 42$ peptide. In line with our findings, several other studies have shown learning and memory deficits in animals expressing wildtype or mutant hAPP not related to the presence of $A B$ (Yamaguchi et al., 1991; Gruart et al., 2008), and it is known that mild overexpression of APP confers an age-dependent progressive and specific memory impairment independent of plaque formation (Moechars et al., 1999; Koistinaho et al., 2001). In mutant APP transgenic mice, knockout of PS1 attenuated A $\beta$ pathology but did not rescue cognitive deficits (Dewachter et al., 2002; Saura et al., 2005). Furthermore, different studies have shown cognitive deficits in the absence of $A \beta$ peptide and cognitive improvement without changes in $A \beta$ pathology (Oddo et al., 2006; Shioi et al., 2007). It was also recently reported that introduction of a mutation that prevents the cleavage of APP by caspases in APP 

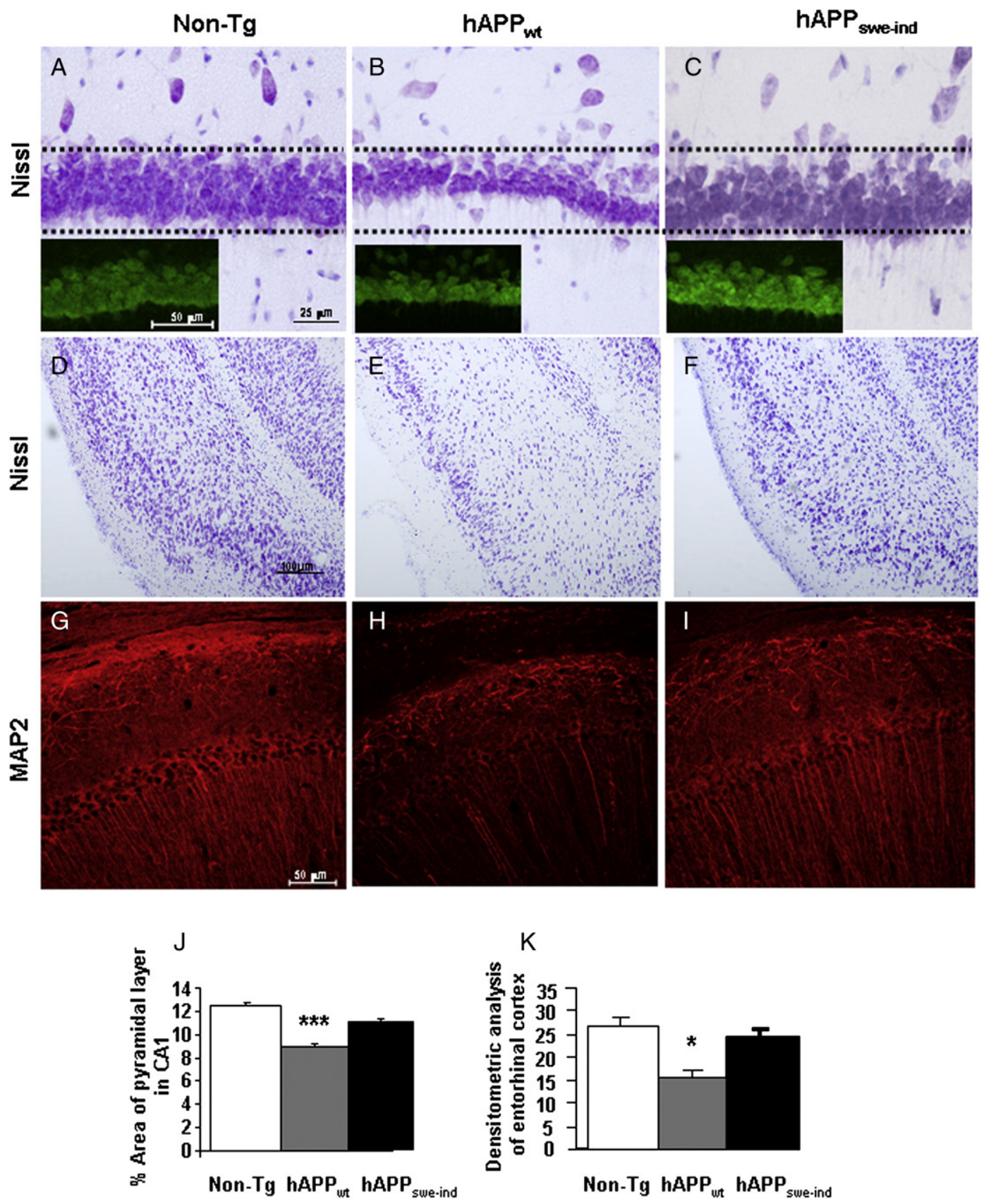

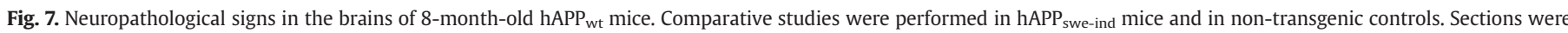

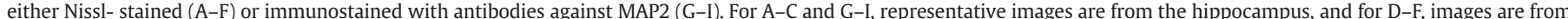

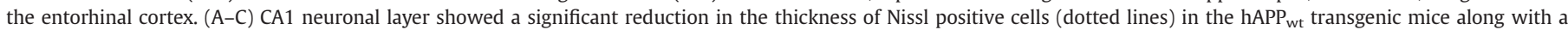

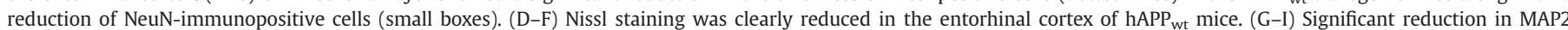

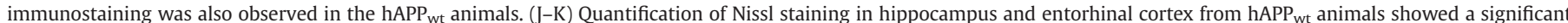

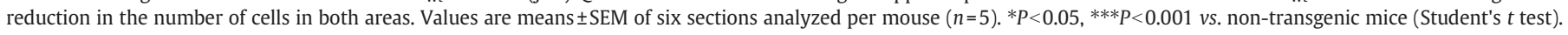

transgenic mice rescued cognitive and pathological deficits but did not affect $A \beta$ loading (Galvan et al. 2006). Indeed, abundant evidences have shown that cognitive decline in AD correlates better with synapse loss or tau pathology than with $A \beta$ plaque burden (Braak and Braak, 1991; Selkoe, 2002; Walsh and Selkoe, 2004). It has been proposed that soluble $A \beta$, rather than insoluble $A \beta$, confers neurotoxicity and it has been recognized that certain species of soluble $A \beta$, such as $A \beta$ oligomers, are neurotoxic and disrupt long-term potentiation. An interesting study with Tg2576 mice overexpressing mutant hAPP reported the presence of an $A \beta 12$-mer oligomer, termed $A \beta * 56$, which seems to be directly related with the appearance of cognitive deficits (Lesné et al., 2006). In hAPP ${ }_{\text {wt }}$ mice, we detected by immunoblotting a weak 56-kDa band that disappeared after HFIP treatment suggesting that this band might correspond to the $A \beta * 56$ oligomer. It is to be supposed that the barely detectable amount of $A \beta 42$ is rapidly polymerized. It is relevant that in $\mathrm{hAPP}_{\text {swe-ind }}$ mice, showing also cognitive impairment and minor histopathological alterations (eg Palop et al., 2003), the ratio of levels of $A \beta * 56$ oligomer vs. APP expression was significantly higher than in $\mathrm{hAPP}_{\mathrm{wt}}$ mice. It is therefore unlikely that the very low levels of this oligomer, as compared to APP levels, may account for the cognitive impairment and neuropathological alterations in mice overexpressing wild-type hAPP. It is also important to note that, according to the amyloid cascade hypothesis (eg Citron, 2004), the abnormal hyperphosphorylation of tau in AD is a 
direct consequence of elevated levels of $A B$ peptide, but in this study we found an increase in phospho-tau in the hippocampus of hAPP $\mathrm{wt}_{\mathrm{wt}}$ mice not related to the presence of $A B$.

Increased APP transcriptional activity constitutes a risk factor for AD (Sleegers et al., 2006; Brouwers et al., 2006; Theuns et al., 2006; Guyant-Maréchal et al., 2007). Indeed, a number of reports indicate that the amount of APP mRNA is increased in autopsied brains of AD patients (Moir et al., 1998; Preece et al., 2004; Matsui et al., 2007) and it is remarkable that overproduction of APP in Down's syndrome leads to clinical $A D$ pathology several years earlier than in the general population (Bush and Beail, 2004; Head et al., 2007). Products derived from APP metabolism, other that AB peptide, in particular CTFs such as C83, C99 and AICD, could play a crucial pathological role in AD (Rockenstein et al., 2005). These derivatives may cause neurodegeneration by promoting apoptosis, alteration of actin dynamics and tau hyperphosphorylation through the regulation of gene expression or by a direct interaction with proteins of the cytoskeleton (Kim et al. 2003; Chang et al. 2006; Lee et al., 2006; Müller et al. 2007). When we analyzed the expression of C83 and C99 fragments in the hippocampus of $\mathrm{hAPP}_{\mathrm{wt}}$ mice we found that APP processing was almost exclusively non amyloidogenic, with high presence of the C83 fragment derived from $\alpha$-secretase cleavage. Of particular relevance is the observation that mice expressing wild-type hAPP have elevated levels of AICD, likely derived from proteolysis of the highly expressed C83 fragment (Waldron et al., 2008). Given the neurotoxic effects of AICD, its presence at elevated concentrations in the hippocampus of $\mathrm{hAPP}_{\mathrm{wt}}$ mice may be responsible, at least in part, for the pathological alterations in these mice. We also found increased levels of phosphorylated CTFs at Thr668 of relevance for regulation of both APP processing and function (Lee et al., 2003; Chang et al., 2006). Particularly, we found a high accumulation of pC83(Thr668) and also a significant increase of the ratio pC99/C99 in hAPP ${ }_{\text {wt }}$ mice which could facilitate the posterior cleavage by $\gamma$-secretase facilitating AICD accumulation (Vingtdeux et al. 2005). The increased levels of phosphorylated CTF in hAPP ${ }_{\text {wt }}$ mice, could probably lead to more AICD available to translocate to the nucleus for inducing neurodegeneration. In this and another related study (Rockenstein et al., 2005) suggesting CTF neurotoxicity in the presence of low $A \beta$ production, no unequivocal evidence is however provided for the molecular species causing neurodegeneration. Other possibilities remain to be explored, in particular the dysfunction of APP signaling induced by wild-type APP overexpression which may lead to cell cycle abnormalities and neuronal cell death (Neve and McPhie, 2007).

Summing up, this study shows that overexpression of wild-type hAPP in mice may recapitulate some crucial features related to Alzheimer's disease such as cognitive impairment, cytoskeletal pathology, synaptic dysfunction and, of particular relevance, signs of neurodegeneration in brain regions directly related to synaptic plasticity and memory. These alterations occur in the absence of significant levels of $A B$ peptide and may be related to hAPP overexpression and the corresponding generation of carboxy-terminal derivatives. The present findings support the relevance of $A \beta-$ independent mechanisms in the pathogenesis of Alzheimer's disease.

\section{Acknowledgments}

This work was supported by Ministry of Education and Science (SAF-2005-05086, SAF-2008-02342), Ministry of Health (CIBERNED), Spain and UTE project FIMA. We thank Dr. L. Mucke for transgenic mice and Dr. J. Palop for helpful suggestions.

\section{References}

Alpár, A., Ueberham, U., Brückner, M.T., Arendt, T., Gärtner, U., 2006. The expression of wild-type human amyloid precursor protein affects the dendritic phenotype of neocortical pyramidal neurons in transgenic mice. Int. J. Dev. Neurosci. 24, 133-140.
Braak, H., Braak, E., 1991. Neuropathological stageing of Alzheimer-related changes. Acta Neuropathol. 82, 239-259.

Broadbent, N.J., Squire, L.R., Clark, R.E., 2004. Spatial memory, recognition memory, and the hippocampus. Proc. Natl. Acad. Sci. U. S. A. 101, 14515-14520.

Brouwers, N., Sleegers, K., Engelborghs, S., Bogaerts, V., Serneels, S., Kamali, K., Corsmit, E., De Leenheir, E., Martin, J.J., De Deyn, P.P., Van Broeckhoven, C., Theuns, J., 2006. Genetic risk and transcriptional variability of amyloid precursor protein in Alzheimer's disease. Brain 129, 2984-2991.

Bush, A., Beail, N., 2004. Risk factors for dementia in people with down syndrome: issues in assessment and diagnosis. Am. J. Ment. Retard. 109, 83-97.

Cabrejo, L., Guyant-Maréchal, L., Laquerrière, A., Vercelletto, M., De la Fournière, F., Thomas-Antérion, C., Verny, C., Letournel, F., Pasquier, F., Vital, A., Checler, F., Frebourg, T., Campion, D., Hannequin, D., 2006. Phenotype associated with APP duplication in five families. Brain 129, 2966-2976.

Chang, K.A., Kim, H.S., Ha, T.Y., Ha, J.W., Shin, K.Y., Jeong, Y.H., Lee, J.P., Park, C.H., Kim, S., Baik, T.K., Suh, Y.H., 2006. Phosphorylation of amyloid precursor protein (APP) at Thr668 regulates the nuclear translocation of the APP intracellular domain and induces neurodegeneration. Mol. Cell. Biol. 26, 4327-4338.

Chen, G., Chen, K.S., Knox, J., Inglis, J., Bernard, A., Martin, S.J., Justice, A., McConlogue, L., Games, D., Freedman, S.B., Morris, R.G., 2000. A learning deficit related to age and beta-amyloid plaques in a mouse model of Alzheimer's disease. Nature 408, 975-979.

Citron, M., 2004. Strategies for disease modification in Alzheimer's disease. Nat. Rev. Neurosci. 5, 677-685.

Dawson, G.R., Seabrook, G.R., Zheng, H., Smith, D.W., Graham, S., O'Dowd, G., Bowery, B.J., Boyce, S., Trumbauer, M.E. Chen, H.Y, Van der Ploeg LH., Sirinathsinghji, DJ. 1999. Age-related cognitive deficits, impaired long-term potentiation and reduction in synaptic marker density in mice lacking the beta-amyloid precursor protein. Neuroscience 90,1-13.

Dewachter, I., Reverse, D., Caluwaerts, N., Ris, L., Kuiperi, C., Van den Haute, C., Spittaels, K., Umans, L., Serneels, L., Thiry, E., Moechars, D., Mercken, M., Godaux, E., Van Leuven, F., 2002. Neuronal deficiency of presenilin 1 inhibits amyloid plaque formation and corrects hippocampal long-term potentiation but not a cognitive defect of amyloid precursor protein [V717I] transgenic mice. J. Neurosci. 22, 3445-3453.

Dodart, J.C., Meziane, H., Mathis, C., Bales, K.R., Paul, S.M., Ungerer, A., 1999. Behavioral disturbances in transgenic mice overexpressing the V717F beta-amyloid precursor protein. Behav. Neurosci. 113, 982-990.

Dunah, A.W., Wang, Y., Yasuda, R.P., Kameyama, K., Huganir, R.L., Wolfe, B.B., Standaert, D.G., 2000. Alterations in subunit expression, composition, and phosphorylation of striatal $\mathrm{N}$-methyl-D-aspartate glutamate receptors in a rat 6-hydroxydopamine model of Parkinson's disease. Mol. Pharmacol. 57, 342-352.

Ennaceur, A., Delacour, J., 1988. A new one-trial test for neurobiological studies of memory in rats. 1: behavioral data. Behav. Brain Res. 31, 47-59.

Echeverria, V., Ducatenzeiler, A., Dowd, E., Jänne, J., Grant, S.M., Szyf, M., Wandosell, F., Avila, J., Grimm, H., Dunnett, S.B., Hartmann, T., Alhonen, L., Cuello, A.C., 2004. Altered mitogen-activated protein kinase signaling, tau hyperphosphorylation and mild spatial learning dysfunction in transgenic rats expressing the beta-amyloid peptide intracellularly in hippocampal and cortical neurons. Neuroscience 129, 583-592.

Ferrer, I., Blanco, R., Carmona, M., Ribera, R., Goutan, E., Puig, B., Rey, M.J., Cardozo, A., Vinals, F., Ribalta, T., 2001. Phosphorylated map kinase (ERK1, ERK2) expression is associated with early tau deposition in neurones and glial cells, but not with increased nuclear DNA vulnerability and cell death, in Alzheimer disease, Pick's disease, progressive supranuclear palsy and corticobasal degeneration. Brain Pathol. 11, 144-158.

Fink, C.C., Meyer, T., 2002. Molecular mechanisms of CaMKII activation in neuronal plasticity. Curr. Opin. Neurobiol. 12, 293-299.

Galvan, V., Gorostiza, O.F., Banwait, S., Ataie, M., Logvinova, A.V., Sitaraman, S., Carlson, E., Sagi, S.A., Chevallier, N., Jin, K., Greenberg, D.A., Bredesen, D.E., 2006. Reversal of Alzheimer's-like pathology and behavior in human APP transgenic mice by mutation of Asp664. Proc. Natl. Acad. Sci. U. S. A. 103, 7130-7135.

Gerlai, R., 2001. Behavioral tests of hippocampal function: simple paradigms complex problems. Behav. Brain Res. 125, 269-277.

Gruart, A., López-Ramos, J.C., Muñoz, M.D., Delgado-García, J.M., 2008. Aged wild-type and APP, PS1, and APP+PS1 mice present similar deficits in associative learning and synpatic plasticity independent of amyloid load. Neurobiol. Dis. 30, 439-450.

Guyant-Maréchal, L., Rovelet-Lecrux, A., Goumidi, L., Cousin, E., Hannequin, D., Raux, G. Penet, C., Ricard, S., Macé, S., Amouyel, P., Deleuze, J.F., Frebourg, T., Brice, A., Lambert, J.C., Campion, D., 2007. Variations in the APP gene promoter region and risk of Alzheimer disease. Neurology 68, 684-687.

Head, E., Lott, I.T., Patterson, D., Doran, E., Haier, R.J., 2007. Possible compensatory events in adult Down syndrome brain prior to the development of Alzheimer disease neuropathology: targets for nonpharmacological intervention. J. Alzheimer's Dis. 11, $61-76$.

Kim, H.S., Kim, E.M., Lee, J.P., Park, C.H., Kim, S., Seo, J.H., Chang, K.A., Yu, E., Jeong, S.J., Chong, Y.H., Suh, Y.H., 2003. C-terminal fragments of amyloid precursor protein exert neurotoxicity by inducing glycogen synthase kinase-3beta expression. FASEB J. 17, 1951-1953.

Koistinaho, M., Ort, M., Cimadevilla, J.M., Vondrous, R., Cordell, B., Koistinaho, J., Bures, J., Higgins, L.S., 2001. Specific spatial learning deficits become severe with age in $\beta-$ amyloid precursor protein transgenic mice that harbor diffuse $\beta$-amyloid deposits but do not form plaques. Proc. Natl. Acad. Sci. U. S. A. 98, 14675-14680.

Lee, M.S., Kao, S.C., Lemere, C.A., Xia, W., Tseng, H.C., Zhou, Y., Neve, R., Ahlijanian, M.K., Tsai, L.H., 2003. APP processing is regulated by cytoplasmic phosphorylation. J. Cell Biol. 13, 83-95. 
Lee, K.W., Im, J.Y., Song, J.S., Lee, S.H., Lee, H.J., Ha, H.Y., Koh, J.Y., Gwag, B.J., Yang, S.D. Paik, S.G., Han, P.L., 2006. Progressive neuronal loss and behavioral impairments of transgenic C57BL/6 inbred mice expressing the carboxy terminus of amyloid precursor protein. Neurobiol. Dis. 22, 10-24.

Lesné, S., Koh, M.T., Kotilinek, L., Kayed, R., Glabe, C.G., Yang, A., Gallagher, M., Ashe, K.H. 2006. A specific amyloid-beta protein assembly in the brain impairs memory. Nature 440, 352-357.

Lu, W., Man, H., Ju, W., Trimble, W.S., MacDonald, J.F., Wang, Y.T., 2001. Activation of synaptic NMDA receptors induces membrane insertion of new AMPA receptors and LTP in cultured hippocampal neurons. Neuron 29, 243-254.

Matsui, T., Ingelsson, M., Fukumoto, H., Ramasamy, K., Kowa, H., Frosch, M.P., Irizarry, M.C., Hyman, B.T., 2007. Expression of APP pathway mRNAs and proteins in Alzheimer's disease. Brain Res. 1161, 116-123.

McGowan, E., Eriksen, J., Hutton, M., 2006. A decade of modeling Alzheimer's disease in transgenic mice. Trends Genet. 22, 281-289.

Moechars, D., Dewachter, I., Lorent, K., Reversé, D., Baekelandt, V., Naidu, A., Tesseur, I., Spittaels, K., Haute, C.V., Checler, F., Godaux, E., Cordell, B., Van Leuven, F., 1999. Early phenotypic changes in transgenic mice that overexpress different mutants of amyloid precursor protein in brain. J. Biol. Chem. 274, 6483-6492.

Moir, R.D., Lynch, T., Bush, A.I., Whyte, S., Henry, A., Portbury, S., Multhaup, G., Small, D.H., Tanzi, R.E., Beyreuther, K., Masters, C.L., 1998. Relative increase in Alzheimer's disease of soluble forms of cerebral Abeta amyloid protein precursor containing the Kunitz protease inhibitory domain. J. Biol. Chem. 273, 5013-5019.

Mucke, L., Masliah, E., Yu, G.Q., Mallory, M., Rockenstein, E.M., Tatsuno, G., Hu, K., Kholodenko, D., Johnson-Wood, K., McConlogue, L., 2000. High-level neuronal expression of abeta 1-42 in wild-type human amyloid protein precursor transgenic mice: synaptotoxicity without plaque formation. J. Neurosci. 20, 4050-4058.

Müller, T., Concannon, C.G., Ward, M.W., Walsh, C.M., Tirniceriu, A.L., Tribl, F., Kögel, D., Prehn, J.H., Egensperger, R., 2007. Modulation of gene expression and cytoskeletal dynamics by the amyloid precursor protein intracellular domain (AICD). Mol. Biol. Cell. 18, 201-210.

Neve, R.L., McPhie, D.L., 2007. Dysfunction of amyloid precursor protein signaling in neurons leads to DNA synthesis and apoptosis. Biochim. Biophys. Acta 1772, 430-437.

Neve, R.L., McPhie, D.L., Chen, Y., 2000. Alzheimer's disease: a dysfunction of the amyloid precursor protein. Brain Res. 886, 54-66.

Oddo, S., Vasilevko, V., Caccamo, A., Kitazawa, M., Cribbs, D.H., LaFerla, F.M., 2006. Reduction of soluble Abeta and tau, but not soluble Abeta alone, ameliorates cognitive decline in transgenic mice with plaques and tangles. J. Biol. Chem. 281, 39413-39423.

Oh, E.S., Savonenko, A.V., King, J.F., Tucker, S.M.F., Rudow, G.L., Xu, G., Borchelt, D.R., Troncoso, J.C., 2008. Amyloid precursor protein increases cortical neuron size in transgenic mice. Neurobiol. Aging (Electronic publication ahead of print).

Palop, J.J., Jones, B., Kekonius, L., Chin, J., Yu, G.Q., Raber, J., Masliah, E., Mucke, L., 2003. Neuronal depletion of calcium-dependent proteins in the dentate gyrus is tightly linked to Alzheimer's disease-related cognitive deficits. Proc. Natl. Acad. Sci. U. S. A. 100, 9572-9577.

Passer, B., Pellegrini, L., Russo, C., Siegel, R.M., Lenardo, M.J., Schettini, G., Bachmann, M., Tabaton, M., D'Adamio, L., 2000. Generation of an apoptotic intracellular peptide by gamma-secretase cleavage of Alzheimer's amyloid beta protein precursor. J. Alzheimer's Dis. 2, 289-301.

Phinney, A.L., Calhoun, M.E., Wolfer, D.P., Lipp, H.P., Zheng, H., Jucker, M., 1999. No hippocampal neuron or synaptic bouton loss in learning-impaired aged betaamyloid precursor protein-null mice. Neuroscience 90, 1207-1216.

Preece, P., Virley, D.J., Costandi, M., Coombes, R., Moss, S.J., Mudge, A.W., Jazin, E., Cairns, N.J., 2004. Amyloid precursor protein mRNA levels in Alzheimer's disease brain. Brain Res. Mol. Brain Res. 122, 1-9.

Priller, C., Bauer, T., Mitteregger, G., Krebs, B., Kretzschmar, H.A., Herms, J., 2006. Synapse formation and function is modulated by the amyloid precursor protein. J. Neurosci. 26, 7212-7221.

Rockenstein, E., Mante, M., Alford, M., Adame, A., Crews, L., Hashimoto, M., Esposito, L., Mucke, L., Masliah, E., 2005. High $\beta$-secretase activity elicits neurodegeneration in transgenic mice despite reductions in amyloid- $\beta$ levels. J. Biol. Chem. 280, 32957-32967.

Rovelet-Lecrux, A., Hannequin, D., Raux, G., Le Meur, N., Laquerrière, A., Vital, A., Dumanchin, C., Feuillette, S., Brice, A., Vercelletto, M., Dubas, F., Frebourg, T. Campion, D., 2006. APP locus duplication causes autosomal dominant early-onset Alzheimer disease with cerebral amyloid angiopathy. Nat. Genet. 38, 24-26.

Saura, C.A., Chen, G., Malkani, S., Choi, S.Y., Takahashi, R.H., Zhang, D., Gouras, G.K. Kirkwood, A., Morris, R.G., Shen, J., 2005. Conditional inactivation of presenilin 1 prevents amyloid accumulation and temporarily rescues contextual and spatial working memory impairments in amyloid precursor protein transgenic mice. J. Neurosci. 25, 6755-6764.

Schiapparelli, L., Simón, A., Del Río, J., Frechilla, D., 2006. Opposing effects of AMPA and 5-HT1A receptor blockade on passive avoidance and object recognition performance: correlation with AMPA receptor subunit expression in rat hippocampus. Neuropharmacology 50, 897-907.

Selkoe, D.J., 2002. Alzheimer's disease is a synaptic failure. Science 298, 789-791.

Shin, R.W., Ogino, K., Shimabuku, A., Taki, T., Nakashima, H., Ishihara, T., Kitamoto, T., 2007. Amyloid precursor protein cytoplasmic domain with phospho-Thr668 accumulates in Alzheimer's disease and its transgenic models: a role to mediate interaction of Abeta and tau. Acta Neuropathol. 113, 627-636.

Shioi, J., Georgakopoulos, A., Mehta, P., Kouchi, Z., Litterst, C.M., Baki, L., Robakis, N.K. 2007. FAD mutants unable to increase neurotoxic Abeta 42 suggest that mutation effects on neurodegeneration may be independent of effects on Abeta. J. Neurochem. 101, 674-681.

Sleegers, K., Brouwers, N., Gijselinck, I., Theuns, J., Goossens, D., Wauters, J., Del-Favero, J., Cruts, M., Van Duijn, C.M., Van Broeckhoven, C., 2006. APP duplication is sufficient to cause early onset Alzheimer's dementia with cerebral amyloid angiopathy. Brain 129, 2977-2983.

Theuns, J., Brouwers, N., Engelborghs, S., Sleegers, K., Bogaerts, V., Corsmit, E., De Pooter T., Van Duijn, C.M., De Deyn, P.P., Van Broeckhoven, C., 2006. Promoter mutations that increase amyloid precursor-protein expression are associated with Alzheimer disease. Am. J. Hum. Genet. 78, 936-946.

Van Dam, D., De Deyn, P.P., 2006. Drug discovery in dementia: the role of rodent models. Nat. Rev. Drug Discov. 5, 956-970.

Vingtdeux, V., Hamdane, M., Gompel, M., Bégard, S., Drobecq, H., Ghestem, A., Grosjean, M.E. Kostanjevecki, V., Grognet, P., Vanmechelen, E., Buée, L., Delacourte, A., Sergeant, N., 2005. Phosphorylation of amyloid precursor carboxy-terminal fragments enhances their processing by a gamma-secretase-dependent mechanism. Neurobiol. Dis. 20 625-637.

Waldron, E., Isbert, S., Kern, A., Jaeger, S., Martin, A.M., Hébert, S.S., Behl, C., Weggen, S., De Strooper, B., Pietrzik, C.U., 2008. Increased AICD generation does not result in increased nuclear translocation or activation of target gene transcription. Exp. Cell Res. 314, 2419-2433.

Walsh, D.M., Selkoe, D.J., 2004. Deciphering the molecular basis of memory failure in Alzheimer's disease. Neuron 44, 181-193.

Winters, B.D., Bussey, T.J., 2005. Glutamate receptors in perirhinal cortex mediate encoding, retrieval, and consolidation of object recognition memory. J. Neurosci. 25, 4243-4251.

Yamaguchi, F., Richards, S.J., Beyreuther, K., Salbaum, M., Carlson, G.A., Dunnett, S.B. 1991. Transgenic mice for the amyloid precursor protein 695 isoform have impaired spatial memory. NeuroReport 2, 781-784.

Zhang, L., Xing, Y., Ye, C.F., Ai, H.X., Wei, H.F., Li, L., 2006. Learning-memory deficit with aging in APP transgenic mice of Alzheimer's disease and intervention by using tetrahydroxystilbene glucoside. Behav. Brain Res. 173, 246-254. 